\title{
Economia solidária \& visão de mundo: a perspectiva biográfica
}

\author{
Alicia Ferreira GonÇalves
}

resumo Este artigo apresenta a narrativa biográfica de um poeta popular nascido no sertão do Estado do Ceará. A narrativa biográfica de Manoel Evangelista de Brito leva-nos a uma incursão ao universo simbólico do homem sertanejo que se transforma com e na história. Acompanhando o sinal dos tempos, nosso poeta é contemporâneo, um homem de seu tempo. De pequeno agricultor sem-terra no sertão cearense, metamorfoseia-se em crítico da política neoliberal e militante da economia solidária na capital. Em sua trajetória há um deslocamento geográfico e simbólico que articula dois planos: estrutura e história. A partir da abordagem biográfica desenvolvida ao longo do artigo podemos apreender o seu valor heurístico para a construção de um conhecimento antropológico dos processos contemporâneos de mudanças (em comunidades pobres) e dos processos que envolvem a (re) significação da estrutura pelos sujeitos sociais.

palavras-chave Narrativas biográficas. Comunidades pobres. Mudanças sociais. Estrutura. Economia solidária.

\section{Introdução}

Assim, o trabalho biográfico e autobiográfico encontra-se no cruzamento de um destino sociológico, cultural e historicamente previsível, de uma memória personalizada desse destino potencial e de um imaginário sensível capaz de seduzir, de tocar emocionalmente, de falar, de interpelar outros inconscientes ou ainda de convencer racionalmente (Josso, 2006, p. 11).
A abordagem biográfica e as narrativas biográficas se constituem como uma dimensão epistemológica estratégica em várias áreas do conhecimento, como história oral, educação, artes, psicanálise, dentre outras. Particularmente na antropologia, a perspectiva biográfica permite ao pesquisador enriquecer sua análise sobre determinados temas, processos sociais, problemas e objetos, a partir da narrativa, que segundo Marie-Christine Josso (Op. cit, p. 11), consiste na reconfiguração do presente e do futuro graças ao olhar retrospectivo: "da invenção de um si autêntico". Ocorre que a construção da narrativa não é arbitrária, e, tampouco, a “invenção de um si autêntico". Neste sentido, Bourdieu (1996) fala da ilusão biográfica e nos mostra que a construção da narrativa se constitui a partir de determinadas posiçóes e deslocamentos no espaço social, neste caso, sempre em diálogo com o contexto social, político, cultural e econômico no qual estáo enredados nossos sujeitos. Portanto, "era indispensável reconstruir o contexto, a 'superfície social' em que age o individuo, numa pluralidade de campos a cada instante" (Levi, 2006, p. 169). É nesta direção que Josso sublinha,

Não é inútil repetir aqui que o trabalho biográfico não é um remoer do passado, mas uma reconfiguração do presente e do futuro graças a esse olhar retrospectivo de um lado e, de outro, ao fato que cada evento ou contexto singular remete imediatamente para referenciais coletivos, quer seja consciente disso ou não (Josso, Op. cit., p. 11). 
Contudo, para além das conexóes entre biografia e contexto, o valor heurístico da perspectiva biográfica reside em alguns aspectos listados a seguir. A biografia é uma fonte de informações sobre o contexto social (Kofes, 1984 e 2001). Isto é, nos informa sobre o contexto de uma época nos alerta Gussi (2002 e 2004) e sinaliza para o tipo de abordagem sociológica (micro ou macro) privilegiada na investigação,

On aura remarque em effect que certains chercheurs ont choisi de se concentrar sur des estructures et des processus 'objectifes', tandis que $\mathrm{d}^{\prime}$ 'autres ont pris pour objet des structures et des processus 'subjectifs' (Bertaux, 1980, p. 203).

A narrativa envolve a evocação da vida vivida pelo sujeito (Kofes, 1984) que ao narrá-la realiza um exercício retrospectivo, auto-reflexivo e prospectivo. E, durante esse exercício, se explicita o caráter textual e ficcional da narrativa, o que nos leva a indagar: de que forma uma vida é narrada? Segundo Benjamin (1985), a narrativa é uma versão factível ${ }^{1}$ da vida vivida, construída com base na relação que se estabelece com aquele que ouve. Segundo a perspectiva antropológica pós-moderna a narrativa biográfica é fruto do encontro etnográfico entre duas subjetividades: entre observador e observado, biografado e autor, neste sentido, a biografia do marroquino Tuhami por Vincent Capranzano (1980), é um exemplo modelar de uma abordagem biográfica escrita nos moldes de um experimento pós-moderno.

A tendência pós-moderna na disciplina se constitui a partir de uma crítica às etnográficas clássicas produzidas entre os séculos XIX e XX na Europa e Estados Unidos denominadas de "realistas"2. A crítica recai sobre os elementos elencados a seguir: 1) autoridade e autoria dos escritos etnográficos que se baseiam em um estilo autoral assumindo dimensões literárias; 2) sobre as explicações totalizantes ou as gran- des narrativas (estruturalismo, funcionalismo e marxismo); 3) o discurso cientificista que caracteriza as etnografias tradicionais, e, 4) as relações de poder assimétricas entre etnógrafo e etnografado. É, pois, se contrapondo a essas características das etnografias clássicas, que as relações estabelecidas entre pesquisador e informante segundo as tendências pós-modernas, podem ser concebidas como um encontro etnográfico. Este encontro pressupóe um ato dialógico simétrico e posteriormente um exercício de interpretação antropológica da narrativa, fixada no texto etnográfico.

Finalmente, a narrativa nos permite uma compreensão densa das experiências e dos processos sociais que investigamos. No caso do presente artigo o foco da abordagem biográfica são os processos de mudanças sociais no Estado do Ceará apreendidas a partir da narrativa biográfica de um poeta popular. Neste caso, a narrativa revela "a relação permanente e recíproca entre biografia e contexto: a mudança é precisamente a soma infinita destas inter-relaçôes" (Levi, Op. cit., p. 180).

Neste sentido, apresento uma análise (no sentido de construir uma leitura sobre) da narrativa biográfica de Manoel Evangelista de Brito que a partir de um exercício retrospectivo, prospectivo e da "invenção de um si autêntico" sinaliza para as possibilidades de mudanças nas condiçóes de vida de comunidades pobres situadas no sertão do Ceará, estado do Nordeste brasileiro, e para as transformações na estrutura social por meio da construção de outra economia $^{3}$ : a economia solidária ${ }^{4}$.

A supracitada narrativa começou a ser construída analiticamente no trabalho de campo quando eu estava realizando uma etnografia das experiências em economia solidária no Ceará entre os anos de 2004 a 20075. Portanto, faço uma distinção entre a narrativa em si do poeta, apreendida por meio das conversas informais, observaçóes de eventos rituais registrados no 
diário de campo, cordéis do poeta e entrevistas (gravadas e transcritas) e a construção analítica da narrativa que ora apresento.

\section{A narrativa}

Assim meus poemas, meus cordéis populares e sociais, fazem um convite especial aos leitores brasileiros a se sentirem incluídos nessa importantíssima tarefa de descoberta da consciência e do saber para a tão sofrida libertação sem exclusáo, uma pátria onde o poeta escreve e canta a verdadeira paz (Brito, 2006, p. 5)

Manoel Evangelista de Brito nasceu aos 27 dias do mês de agosto de 1936, em uma comunidade de nome Vaca Morta na região de Boa Fortuna, município de Quixadá - sertão do Ceará. Descende da linhagem de uma família de pequenos agricultores, segundo filho de uma série de dezesseis. Trabalhou na terra da família juntos com os irmãos homens até 1957. Casou-se em 1960, aos 25 anos com dona Maria do Carmo com quem teve treze filhos.Viveu da agricultura de subsistência até 1975. Após vários períodos de seca mudou-se com a família para uma indústria de processamento e beneficiamento da castanha e do caju onde se empregou. No ano de 1977, ingressou no ramo da construção civil, entrou para o sindicato e aposentou-se em 2000. Em 1980 foi viver na capital do Estado em uma área de risco social. Sua trajetória descrita em versos de cordel é igual à de milhóes de camponeses nordestinos que na década de 70 migraram em direção às capitais brasileiras em busca de emprego, geralmente na construção civil.

Manoel Evangelista de Brito define a si mesmo como um poeta popular. Nosso poeta escreve poesias em estilo de cordel, nas quais realiza um exercício retrospectivo, prospectivo e reflexivo sobre vários temas que se entrecruzam e se organizam a partir de uma lógica binária e contrastiva: a água em contraposição à seca, o sertão como o contrário do mar, o campo em contraste com a cidade. Os pares de opostos referem-se ao processo de migração do campo em direção à cidade, à exploração capitalista no campo e a contradição imanente ao seio do sistema, qual seja, a contraposição de interesses entre capitalistas e trabalhadores ${ }^{6}$.

Seus cordéis retratam ainda da tradição cultural nordestina, do regionalismo, neoliberalismo, dos direitos, da dignidade, da cidadania, da sobrevivência, da fome, da espiritualidade e da esperança. E, por fim, sua narrativa remete ao grande contraponto: a economia solidária que se contrapóe à economia capitalista e constrói a utopia da nova sociedade. Manoel Evangelista é um personagem significativo no universo local da economia solidária e dos movimentos sociais no Ceará.

Sua narrativa leva-nos a uma incursão ao universo simbólico do homem sertanejo, que se transforma com e na história, acompanhando o sinal dos tempos. Nosso poeta é contemporâneo, um homem de seu tempo. De pequeno agricultor sem-terra no sertão cearense, metamorfoseia-se em crítico da política neoliberal e militante da economia solidária na capital. Em sua trajetória, há um deslocamento geográfico ${ }^{7}$ e simbólico que articula dois planos: estrutura e história ${ }^{8}$.

No cordel Lendas de poesia (2008) Manoel Evangelista se refere ao contraste entre o sertão e o mar - pares de opostos que denunciam as condiçóes de vida de pequenos agricultores que vivem no semiárido nordestino. Nosso poeta tem ciência da exploração que sofre do "patrão", motivo que o fez migrar com a família em direção ao mar,

No mundo capitalista os pobres sofrem demais o mercado toma tudo o quanto o camponês faz em um sistema capaz levam o lucro da produção 
entre o banqueiro e o patráo foi essa bruta esperteza que me trouxe a Fortaleza deixando para lá o meu sertão. Com dívida e falta de apoio eu já não resisti mais imigrei com a família deixando tudo para trás despedi-me dos meus pais de minha casinha e meu chão em cima de um caminhão trazendo a dor e a incerteza partindo para Fortaleza sem esquecer meu sertáo (Brito, Op. cit., p. 12).

Eu vivia em Quixadá cultivando a terra benta cheguei aqui em oitenta a procura de um lugar para morar e trabalhar fiquei na periferia enfrentando o dia-a-dia trabalhando de pedreiro ganhando um mixo dinheiro no arrocho da carestia (Op. cit., p. 16).

Os seus versos em forma de cordel revelam, sobretudo, a condição sertaneja: a seca, a pobreza e a fome. Sua poesia denuncia a estrutura fundiária do Nordeste brasileiro, caracterizada pela exploração capitalista no campo e pelo grande latifúndio. Expropriando milhares de pequenos agricultores que em busca de água e de uma vida melhor migram em direçáo ao mar e à cidade grande. Uma estratégia dos agentes, como diria Bourdieu (2006), para se desvencilhar da estrutura. Manoel Evangelista que por anos trabalhara as terras da família, endividado, opta por migrar para a capital em busca de emprego e melhores condiçóes de vida para sua família.

Em 1980, chegou ao Conjunto Palmeiras da região do Grande Jangurussu, onde construiu sua casa após longos anos de labuta na construção civil; até então, nunca ouvira falar em economia solidária. $\mathrm{Na}$ apresentação de seu memorial, publicado em formato de folhetim no estilo de poesia de cordel, ele diz: "Foi assim meus caros leitores que o humilde camponês, um dos milhóes de migrantes que vem para a cidade grande 'Fortaleza', vim para capital. Tornando-me operário da construção civil" (Brito, Op. cit., p. 5) ${ }^{9}$. Manoel Evangelista chegou ao Conjunto Palmeiras em 18 de outubro de 1980, quando construiu "um barraco" na Rua Maíza, 801 onde mora até hoje ${ }^{10}$. A narrativa seguinte resgata o contexto dos anos 1980 quando Manoel Evangelista e sua família chegam ao Conjunto Palmeiras. Anos antes trabalhara no processamento da castanha de caju nas terras de um grande latifundiário. Migra para a capital em busca de garantias trabalhistas empregando-se na construção civil,

Eu cheguei aqui (Conjunto Palmeiras) em outubro de 1980, o bairro o Palmeiras surgiu em 1974, eu cheguei em outubro de 1980 e ainda hoje estou por aqui. Quando nós chegamos aqui, eu sou de Quixadá, eu vim de Quixadá, mas não vim direto eu sai de lá em 1975, da minha região, Serra Azul, vim com a família morar na fazenda da Sione. Trabalhava com caju e castanha e passei lá dois anos, mas ai eu sai do campo e queria assinar uma carteira, para ter os direitos trabalhistas aí surgiu o emprego na BR116 para trabalhar na Construtora Andes. Eu entrei como encarregado de turma e fique lá em 1977 até 1980, quando eu vim para cá, fui botado para fora da firma eu vim embora para cá, compramos um terreninho neste local, e construímos a casa e fui trabalhar na construção civil, trabalhei de pedreiro até 1989. Eu entrei no sindicato dos trabalhadores da construção civil fiquei no sindicato até me aposentar em 2000 (Entrevista realizada com Manoel Evangelista, 2006).

No início da década de 70, segundo Paulino (2007), há um processo de segregação social nas grandes capitais brasileiras - confinando comunidades pobres às áreas de risco. Esse processo fazia parte das políticas do projeto desenvolvimentista do governo militar no Brasil. No Ceará esse processo foi nomeado de "modernização", 
Há 33 anos (1973), iniciava-se o assentamento das primeiras famílias, oriundas de diferentes áreas de risco da cidade e também de regióes centrais onde a especulação imobiliária já impulsionava a expulsão de famílias assentadas em espaços que passaram a interessar no processo de "modernização" da capital do Ceará. Assim, o povoamento do Conjunto Palmeiras deu-se a partir de uma ação executada pela Prefeitura Municipal de Fortaleza, em plena vigência do autoritarismo desenvolvimentista que caracterizou o governo dos militares (Paulino, 2007, p. 3).

No contexto do conjunto de migraçóes em direção à cidade e de "modernização" da capital do Estado, Manoel e a sua família vieram morar em uma área geográfica considerada de risco em função dos graves problemas sociais e ambientais que ali se concentraram. Durante anos a regiáo serviu como aterro sanitário onde era depositado o lixo de toda a cidade, que por vezes funcionava também como meio de sobrevivência para a maioria dos moradores. Além do aterro, a região foi palco de invasão de terras, violência contra a mulher, criminalidade e tráfico de drogas. Alto índice de analfabetismo, ausência de infra-estrutura como, transporte, água, saneamento básico e escolas caracterizavam o Grande Jangurussu, nos anos 1970 e 1980, como área de alta vulnerabilidade social, como conta nosso biografado sobre as condiçóes de vida da comunidade que recém se constitui enquanto tal,

Mas a história do Palmeiras, nós chegamos aqui, isso aqui era mato, a maioria dos terrenos era mato, as casas eram distantes uma das outras, e não tinha ruas, ruas só mais lá para o centro, a gente chama de Sobral, na rua Codó, aqui não tinha nada era mato, tinha uma rua formada lá de casas mais aproximadas, umas casas que foi feita pelo padre Souto que deu uma ajuda ao pessoal e chama rua do padre Souto. Rua Cantareira, a última rua ao lado no terreno do Jorge Vieira, e nós fomos construindo. Aqui não tinha água, não tinha energia, não tinha nada, a água era de carro pipa e de umas caçambas que tinha lá no início do Palmeiras e a gente pegava lá. Energia eles foram colocando aos poucos, em poucas casas, formava um quarteirão eles vinham e colocavam um poste. Nós começamos a nos organizar, minha esposa Maria do Carmo era representante de quadra ela foi várias vezes para Coelce. Nós chegamos em 1980, ficamos no escuro três anos só na base da lamparina. Água era carro pipa, seis anos quase não chovia e ficamos sem água, foram tempos difíceis, eles fizeram quatro chafarizes aqui na Rua Silvinha Teles, a gente pegava água lá, era uma fila e o pessoal brigava na fila. Quando foram aumentando as famílias, vieram muitas famílias do interior, aí o chafariz não deu mais conta, de dois em dois dias vinha o carro pipa, fazia filas na pipa, na época era o padre Eduardo e Jacob, eles deram muita ajuda nesta parte. Mercado era buteco na rua, Dionísio, ele hoje não tem mais comercio dele, hoje a gente usa o frigorífico do centro. Tinha uns 4 comércios maiores. $\mathrm{Na}$ época quando chegamos tinha dois ou três ônibus por dia, você ia pela manha todo mundo pendurado dando prego aqui e acolá, e ai eles ás vezes para voltar, voltava tarde da noite, quem carregava água na cabeça eram as mulheres e as crianças porque os homens iam trabalhar, a não ser de madrugada (Entrevista realizada com Manoel Evangelista, 2006).

A narrativa biográfica que se constitui no plano das micro-relaçóes sociais e que nos fala sobre a vida em uma comunidade pobre situada na capital do Ceará nos remete ao contexto mais amplo dos anos 1990 quando Fernando Collor de Melo derrotou o candidato do Partido dos Trabalhadores e assumiu o governo federal. Fernando Collor em sua breve gestáo executou um conjunto de políticas de corte neoliberal, dentre elas, a abertura comercial, neste processo muitas empresas nacionais faliram, por não serem com- 
petitivas. Este fator, aliado aos processos de reestruturação produtiva e à introdução de novas tecnologias nas empresas produziram o desemprego estrutural nos grandes centros urbanos ${ }^{11}$. As pessoas desempregadas começaram a compor o mercado informal de trabalho. Enquanto isso, como contraponto às políticas neoliberais, os movimento sociais no campo e na cidade apoiados pelas Pastorais e Comunidades Eclesiais de Base (CEB'S) organizaram-se reivindicando emprego, moradia, saneamento básico, transporte, educação, enfim, melhores condições de vida, a narrativa seguinte descreve esse processo de organização política da comunidade,

A partir dos anos 90 o pessoal começou a se organizar e já tinha luz em quase todos os locais. Foi uma luta em 1989, a luta por água foi muito grande foi em 1988.O Tasso Jereissati foi eleito, o pessoal fez uma caminhada umas três vezes para o Cambeba, água, moradia, o principal ponto da luta era água. $\mathrm{O}$ pessoal faltou morrer de sede mesmo, quando foi em 1989 colocaram água em todas as casas e foi melhorando um pouco a educação, a energia elétrica chegou em 1986, já tinha luz em todas as casas. De 1987 a 1990 foi a luta pela educação, para concluir os colégios que tinham aqui. Asfalto, calçamento, essa linha de ônibus, foi uma luta muito grande dos jovens, tinha um grupo chamado Jupispa e a Associação de moradores fundada em 1982. Eu sempre fui associado, mas nunca fui presidente até porque nessa época eu trabalho mais na construçáo civil eu me associei e ajudava muito, mas nunca me candidatei a presidente. Em 1987 com a chegada dos padres Luis e Chico da Itália, passaram por São Paulo e chegaram em 1987. A Igreja foi fundada junto com o Palmeiras, uma igrejinha pequena o pessoal se organizou e construiu a Igreja do padroeiro que é São Francisco Assis (Entrevista realizada com Manoel Evangelista, 2006).
No Ceará, as famílias pobres de Fortaleza e aquelas que migraram do campo (dos interiores) se articularam aos movimentos sociais, às CEB'S e às Pastorais para reclamar dos governos municipal e estadual em um primeiro momento moradia e água. Uma dessas famílias era a de Manoel Evangelista. Manoel Evangelista que viera do trabalho agrícola, migrando para o trabalho da colheita e processamento do caju, recém-chegado a capital do Estado, se emprega na construção civil e juntamente com outras famílias pobres começa a reivindicar melhores condiçôes de vida e a infra-estrutura para o bairro que se chamaria Conjunto Palmeiras. Nesse exato momento nosso poeta começa a se construir como uma liderança comunitária de destaque. E, como liderança comunitária organiza politicamente a comunidade com o apoio dos padres, como indica sua entrevista. Foi uma luta de aproximadamente vinte anos, inicialmente por água encanada e transporte, depois por escolas, creches e emprego.

Sua conversão em liderança comunitária no Conjunto Palmeiras é narrada também em seus versos. No cordel o poeta narra a necessidade de organização social das famílias na luta por melhores condições de vida - em suas palavras, na luta contra o "sistema" e os "patrôes". Em sua narrativa podemos apreender a atuação política do poeta que começa quando (chega à capital) como militante do movimento sindical e das comunidades eclesiais de base denunciando em seus cordéis a exploração capitalista e as condiçôes de vida dos migrantes,

Chegando aqui na cidade foi preciso me organizar para enfrentar o tal sistema tem que aprender a lutar. Fui convidado a me engajar nas Ceb's e nas pastorais, nos movimentos sindicais, pra enfrentar os patróes com direito a formação que mostra a realidade. Pois os patrôes da cidade são os mesmos lá do sertão (Brito, Op. cit., p. 12). 
Manoel Evangelista sublinha a ação da Igreja Católica via Pastorais que atuavam nas comunidades pobres segundo a perspectiva da Teologia da Libertação. Nosso poeta justifica a mudança de foco na sua atuação: das portas das fábricas aos projetos associativistas que tinham como finalidade elaborar projetos de geração de emprego e renda em sua comunidade ${ }^{12}$.

Sua narrativa nos remete novamente ao contexto do final dos anos 1990, com o aumento do desemprego estrutural e do trabalho informal a comunidade organizada em associaçóes de bairros e apoiadas pela Pastoral Operária elabora estratégias para a geração trabalho e renda, como por exemplo, a formação profissional. Neste processo de ação comunitária Manoel Evangelista teve papel de destaque como liderança e na criação de uma associação na comunidade. Em suas entrevistas enfatiza sempre o papel da Pastoral e dos padres que apoiaram a formação da associação comunitária Santo Dias:

A Pastoral existia no Brasil desde 1977, mas aqui foi fundada desde 1987 e estamos trabalhando com a Pastoral esse tempo todo.Muito na porta de fábrica, na época do emprego, das chamadas dos sindicatos a gente participou das lutas sindicais e na década de 90 , de 97 a 98, não pudemos mais atuar nas portas de fábricas e a pressão foi muito grande e dava desemprego, aí gerou a polêmica dando a entender que estávamos atrapalhando os trabalhadores, a Pastoral resolveu trabalhar nos bairros. É um movimento da igreja católica. Ela nâo fica dentro das questôes, na questão política trabalha mais na formação de qualquer pessoa, de qualquer partido, a gente provoca debates nas comunidades, qual é o direito e deveres de cada trabalhador, de cada morador de bairro. Era a Pastoral e a Associação de moradores a partir dessa época que lutamos contra o desemprego e começamos a trabalhar com a formação, educação profissionalizante com educação básica, com jovens e adultos, com projeto piloto a partir da terceira e quarta série e em 1997, criamos a Associação Santo Dias, para a gente ter direito a arrecadar fundos para trabalhar com essas coisas, para criar projetos a gente tem que ter uma Associação. Associação sem fins sociais. Ela fica mais no Parque Santa Maria. E a partir daí começamos a trabalhar com a formaçáo depois do projeto piloto, criamos o Projeto Reconquistar um projeto que avançou muito jovens e adultos, mais jovens e a partir daí surgiu a idéia de pessoas formadas no Reconquistar dar formaçáo no cooperativismo (Entrevista realizada com Manoel Evangelista, 2006).

Em sua narrativa, nosso personagem enfatiza a relevância do Projeto Reconquistar na comunidade $^{13}$. Em sua fala ele cita a ação pioneira da Pastoral Operária nessa região: uma pesquisa junto às famílias da região, onde foi constatado alto índice de desemprego, ausência de saneamento básico, de escolas e de segurança. A Pastoral com o apoio da liderança comunitária delineou sua atuação para a formação profissional, educação básica e cidadania. Não se tratava apenas de reivindicar saneamento básico e emprego, mas, sobretudo, de formar consciências críticas, educar para o exercício da cidadania e para a construção de uma nova sociabilidade. Trata-se da construção da utopia da nova sociedade. Neste sentido, há uma dimensão pedagógica significativa subjacente às ações da Pastoral, que é justamente a de manter a identidade da classe trabalhadora, o resgate da auto-estima e a construção de uma nova cultura do trabalho, com base no espírito coletivo e de partilha e nos laços de solidariedade; "portanto, sem as relaçóes de exploração, que são próprias do capitalismo" (Pastoral Operária, 2005, p. 1).

A formação em cooperativismo na perspectiva da economia solidária foi considerada uma estratégia fundamental para a geração de trabalho e renda segundo a narrativa. Por outro lado, a narrativa revela a relevância dos ensinamentos da Pastoral na visão de mundo de nosso poeta 
que a partir de então, se converte também em militante da economia solidária, pratica a solidariedade, ajudando a organizar as cooperativas no Conjunto Palmeiras, dentre elas, a Coopsol, formada por mulheres costureiras:

A ideia foi da Pastoral de trabalhar em cooperativas, nós pegamos essa ideia exatamente que a gente foi entendendo que as pessoas saem de um projeto de formação profissionalizante e essas pessoas vão para o mercado formal e náo encontram vaga. Seria importante para essas pessoas trabalharem por conta própria e se agrupassem para trabalhar no modelo solidário, nas comunidades. Veio essa ideia da Coopsol pelas senhoras que estavam na época lá que era a Conceição que hoje ela e a Lúcia fazem a cabeça da Coopsol. Iniciaram lá, muitas pessoas entraram e saíram, mas elas permaneceram porque elas têm uma formação básica em cooperativismo (Entrevista com Manoel Evangelista, 2006).

Um das primeiras experiências nos moldes do cooperativismo e da economia solidária no Conjunto Palmeiras, foi a COOPSOL formada por mulheres costureiras. No processo de constituição da cooperativa, Manoel Evangelista, apoiado pela Incubadora de cooperativas da Universidade Federal do Ceará (UFC), UNITRABALHO e pela Agência de Desenvolvimento Solidário (ADS/CUT), desempenhou papel central na formação das mulheres em cooperativismo e economia solidária, como conta com orgulho em entrevista:

Foi muito difícil trabalhamos quase cinco anos, muitos dando apoio as elas de formaçáo e tivemos cinco ou seis reunióes com o pessoal da Incubadora de Cooperativas. $\mathrm{Na}$ época tinha o pessoal da UFC dando curso trabalhando junto tivemos com o pessoal da UNITRABALHO. Foi a UNITRABALHO que nos encaminhou nesse processo para ter o conhecimento com a Incuba- dora de Cooperativas. Foi com ela (incubadora) que elas se formaram. Estamos na luta com quase dois anos que está oficializada a Coopsol, foi a primeira cooperativa oficializada de costura e confecção feminina no Estado do Ceará (Entrevista realizada com Manoel Evangelista, 2006).

Nós não estamos no pé delas agora não para elas andarem com o pé no chão. No começo todos os meses nós tínhamos reunião com elas e com o grupo. Dando informaçóes, foi uma luta grande mesmo. Quando nós iniciamos começamos a trabalhar com quatro grupos, dois aqui no Palmeiras, um no Paulo II e dois no Parque Santa Maria, a idéias é que elas se juntem para trabalhar (em um mesmo espaço físico). Elas estão com a sede no João Paulo II e estão tentando negociar a sede que era da Associação e eles cederam e elas estão querendo fazer uma reforma elas estão animadas para fazer uma reforma e dar continuidade (Entrevista realizada com Manoel Evangelista, 2006).

Vejamos, a narrativa sinaliza o envolvimento de Manoel Evangelista com a Universidade e a Incubadora de cooperativas. Neste exato momento passa a ser também um difusor dos princípios do cooperativismo. Pois, incorpora em seu vocabulário conceitos e categorias oriundas do universo acadêmico, tais como, luta de classes, consciência de classe, economia burguesa, dentre outros. Caminha junto com as mulheres costureiras em sua empreitada e vivencia as dificuldades do empreendimento solidário em um mundo capitalista. Em sua fala afirma que a despeito da formação que receberam em cooperativismo e economia solidária, as costureiras não conseguiam vender suas mercadorias, saldar seus compromissos financeiros e gerar renda, em suas palavras: "O mais difícil é esse lado: esse choque entre a economia burguesa e a economia de quem está iniciando" (Brito, 2006); 
O mais difícil é esse lado: esse choque entre a economia burguesa, de capital evoluído e a economia de quem está iniciando, que é trabalhar com o mesmo grupo que a gente sabe que era o essencial: que são os mais pobres (Entrevista realizada com Manoel Evangelista, 2006).

Neste sentido, a narrativa revela as tensões entre a estrutura e a ação social, em uma sociedade de mercado onde o simbolismo econômico é estruturalmente determinante. Não se trata apenas de limites de ordem econômica, mas sim, de limitaçóes que remetem ao plano das representaçóes. A narrativa conta que

Muitos não sabem da existência da economia solidária, ou muitos já ouviram falar e não sabem por que ela existe. O Conjunto Palmeiras tem 70.000 de 89 para cá. Acredito eu que teria ser uma luta muito grande de formação do povo, não acredito que as pessoas saibam das coisas sem ter quem informe. Essa formação tinha que ser nas Associaçóes de moradores de bairro, a igreja, incluindo os partidos que estão do lado do povo, e que isso se tornasse uma voz, que o pessoal entendesse isso (Entrevista realizada com Manoel Evangelista, 2006).

É um povo desempregado reinventando uma nova economia pela obrigaçáo de vida e entrando em choque, porque há uma falta de compreensão porque o pessoal não entende que essa economia solidária seria um desenvolvimento dos pobres com os pobres. Seria um mercado diferente. Não se faz nada diferente se não há diferenças. Porque não tem diferença aí, o pobre com espirito de burguês ele só compra de marca. Não podemos começar uma coisa com marca de primeira. Os outros ficam alheios a esse conhecimento, nós temos trabalhando bastante, mas uma Pastoral em uma área dessas, a tendência é não crescer muito (Entrevista realizada com Manoel Evangelista, 2006, grifo meu).
Neste sentido, com recorrência a narrativa sublinha as dificuldades das experiências em economia solidária, vivenciadas por ele junto à cooperativa de mulheres, uma vez que participava do seu cotidiano. Como bem o demonstram suas falas, dificuldades de comercialização dos produtos e falta de um mercado consumidor na própria comunidade. Ele identifica as causas das dificuldades enfrentadas pelos empreendimentos solidários no desconhecimento das pessoas sobre o significado profundo da economia solidária em comunidades pobres e da ausência de uma "consciência de classe", por isso menciona "o pobre com espírito de burguês". Portanto, para além das limitaçóes estritamente econômicas, isto é, na esfera da circulação de mercadorias, podemos considerar que há fortes entraves no plano simbólico, onde segundo Sahlins (1979), o simbolismo econômico é estruturalmente determinante.

Percebemos por meio de sua narrativa que nosso poeta tem a consciência exata do funcionamento da economia capitalista. Ao longo de sua trajetória aprendeu a partir de um exercício reflexivo e dialógico com os sindicatos, movimentos sociais, pastorais e com a universidade sobre as contradições do sistema capitalista e da estrutura que limita as açóes dos movimentos sociais, dentre eles o movimento da economia solidária. Neste sentido, trata-se de uma narrativa exemplar em que as categorias produzidas no universo acadêmico são (re) significadas pelos sujeitos a partir de suas próprias categorias simbólicas ${ }^{14}$.

Em sua narrativa, Manoel Evangelista denuncia a forma como o mercado opera e exclui as cooperativas solidárias - fala que o mercado é perigoso em entrevista: "Elas fazem uma mercadoria da maneira que o mercado exige, elas fazem, só que elas têm que caprichar muito e sai muito caro para disputar com o mercado lá fora” (Brito, 2006). Mas ainda assim, menciona a esperança. Neste sentido, tanto em suas entrevistas como na literatura de cor- 
del, denuncia as dificuldades das pessoas que estão em situação de vulnerabilidade social de se inserir em um mercado de trabalho formal. Por outro lado, menciona as limitaçóes dos empreendimentos solidários conviverem às margens da economia mercantil. Porém, como tem esperança, crê na possibilidade dos sujeitos da economia solidária reverter o processo, por meio de um aprendizado das regras de mercado, como sinalizam as falas seguintes:

É muito difícil ainda porque o mercado impede que as pessoas façam um trabalho solidário e acessível, que elas tenham condiçóes para ela ganhar o real para elas se manterem. Elas vão começam a funcionar, levantam, caem, mas elas estão resistindo bem. Aprendendo mais, estão se dando mais com o mercado, estão sabendo que é difícil, mas já sabem fazer as coisas (Entrevista realizada com Manoel Evangelista, 2006).

O que falta é compreensão das comunidades de abraçar essa chamada Economia Solidária, porque elas estáo dependendo do mesmo mercado do capital. Das outras grandes empresas, elas estão dependendo da mesma linha de mercado das grandes empresas, se as comunidades pobres da região que a gente trabalha, do povão desempregado entendessem que isso é lado que iria transformar um mercado diferente, acredito eu, que uma cooperativa seria uma luz em uma comunidade uma coisa que ia garantir muita coisa (Entrevista com Manoel Evangelista, 2006).

O principal desafio é o comércio é como comercializar, porque se a pessoa faz, mesmo que ela faça um empréstimo, mas ela se ela não tiver a linha de mercado garantida, corre o risco de empacar a mercadoria e não pode demorar porque a confecçáo é aquele tipo de coisa, se você empaca vem outro modelo, no mínimo três meses e você tem que mudar alguma coisa. O tempo em que elas se garantem o mercado é quando tem copa do mundo, se elas tiverem prontas e se o grupo tiver animado, tem um ganho real porque elas vão fazer e vão vender. Mas o mercado é perigoso porque faz e se não tiver a garantia do mercado dificilmente elas vão garantir que a cooperativa ela deslanche e ganhe dinheiro. O nosso objetivo seria um grupo de oito a dez mulheres, é que elas tivessem as condiçóes de retirar ao menos um salário mínimo para elas se manterem, mas elas ainda não conseguem isso. Algumas vezes, em uma copa de mundo, por exemplo, janeiro, fevereiro e março é um tempo difícil. Se elas não fossem bem formadas para o que elas estáo vivendo, elas desistiriam porque aí fica difícil (Entrevista realizada com Manoel Evangelista, 2006, grifo meu).

Como vimos, Manoel Evangelista constitui sua narrativa a partir de uma lógica binária, pois, aborda as contradiçóes que atravessam a economia solidária como o mercado e o plano das representaçôes e ainda assim, menciona a esperança, a solidariedade e a espiritualidade. Opóe no plano simbólico capitalismo e solidariedade, capitalismo e espiritualidade. Sua visão de economia solidária é aquela que aprendeu com a Pastoral, em suas palavras: "se trata de uma economia reinventada pelos pobres sem emprego e para os pobres". Trata-se de uma espiritualidade que se casa com as lutas sociais e se imbrica na economia, ou seja, trata-se de uma economia enraizada socialmente como diria Karl Polanyi (2000) ${ }^{15}$. Passemos à narrativa:

Isso é interessante, é uma espiritualidade que é casada com o social. Quer dizer, se você diz que é cristão, se você é uma pessoa que gostou da idéia de Jesus Cristo ter morrido na cruz pelos pobres e vê o sofrimento dos outros e deixa para lá e vai cuidar de si aí também tem outro lado da história. A Pastoral Operária a gente sempre em nossas oraçôes tem essa leitura na cabeça (Entrevista realizada com Manoel Evangelista, 2006). 


\section{A utopia da nova sociedade}

A despeito de o simbolismo econômico ser "estruturalmente determinante", a narrativa nos permite vislumbrar possibilidades de mudanças na sociedade ${ }^{16}$. Em Lendas da poesia, Manoel diz que a mudança virá com o "desenraizamento da cultura antiga” (Brito, Op. cit., p. 12), com a descoberta das consciências e com a mudança no pensamento do Homem. Aí reside a esperança e nasce a solidariedade.

A descoberta das consciências está ligada ao conhecimento adquirido junto às universidades, contudo, em sua visão, as universidades têm dificuldades de disseminar esse novo conhecimento junto às "bases", em suas palavras,

Cresce o conhecimento porque a gente participa de debates, estudamos livros importantes que são feitos nas universidades, vocês da universidade trazem esses conhecimentos que eu sei que tem. Vêm as meninas da universidade que fazem perguntas que eu fico embelezado com esse conhecimento. Mas tem essas dificuldade de ir para as bases e disseminar esse conhecimento. Para se ter uma coisa que prega mesmo, é uma cultura muito antiga, para que isso se desenraize do coração das pessoas, da mente das pessoas, é uma tremenda de uma dificuldade (Entrevista com Manoel Evangelista, 2006).

Eu fico imaginando assim, é de você dormir e acordar, sonhando com essas coisas, quem sabe que esse dia é táo importante, você fazer uma coisa que todo mundo abraçasse igualmente, todo mundo sobrevivia mesmo que começasse a sentir um pouco as dificuldades mas lá adiante vê uma riqueza que as pessoas dividissem o que produz, o que faz com que produz (Entrevista com Manoel Evangelista, 2006).

Manoel Evangelista, convertido em militante da economia solidária, menciona a utopia da nova sociedade a partir do trabalho cooperativo. Neste sentido, se a narrativa articula estrutura e mudança, poderíamos, então, imaginar pequenas transformações na estrutura a partir do "novo", desta "outra economia"? Assim como a chegada do capitão James Cook ao Havaí fora incorporada pelos havaianos nos termos de sua própria mitologia e (re) significada a partir dos diversos interesses em disputa, como nos descreve Sahlins (1990), poderíamos pensar que a economia solidária fora (re) significada por Manoel Evangelista a partir de suas próprias categorias simbólicas?

Ao longo de sua trajetória - de pequeno agricultor no sertão nordestino sem água a militante da economia solidária na capital do Estado houve uma reavaliaçáo dos significados e a reorganização das velhas categorias. Neste exercício reflexivo, segundo seu entendimento, o modelo capitalista de sociedade torna precárias as relaçóes de trabalho e as condiçóes de vida das comunidades pobres. Passemos à narrativa:

Para ser da Pastoral Operária tem que estar no meio dos pobres tanto é que a gente deixou o lado que era táo bonito e interessante que era ir para a porta de fábrica, discutir com os trabalhadores nos bairros, tinha um número muito grande de trabalhadores na construção civil, a gente discutia os problemas. Percebemos que não tínhamos mais nada que discutir com os trabalhadores. chega lá é uma coisa bem diferente, trabalhador não se da mais conta de dizer que os patróes os fazem aceitar as misérias que eles impóem que o mercado é bruto, o cara mal sai e tem outro na vaga, ai não daria mais para nós. Resolvemos náo deixar eles de lado passar para eles a formação de que nos não podemos ir até onde a gente gostaria a gente sabe que é um tempo passageiro nunca foi assim, toda vida isso surgiu bem depois dos cristãos que existem gente no mundo, como a tendência é mudar as pessoas váo se formando para um novo contexto $d a$ 
sociedade que seria trabalhar o solidário e reinventar um novo modelo, uma nova economia, estamos no começo do processo e o povo ainda náo entende isso. (Entrevista com Manoel Evangelista, 2006, grifo meu).

A narrativa sugere que a despeito do simbolismo econômico ser estruturalmente dominante no modelo capitalista de sociedade, as comunidades pobres tem o potencial de projetar para o futuro um modelo diferente de sociedade a partir das experiências em economia solidária. A solidariedade seria o elemento central nesse micro processo de mudança social:

As discussões de cooperativas que nós tivemos com elas foram muitas. É por isso que têm algumas delas que não saem. Porque elas colocaram isso no coração e sabem que é a coisa mais legal e mais bonita que existe é você valorizar o seu trabalho em conjunto. Eu faço, se eu sofrer, eu sofro junto. Se eu ganhar eu ganho junto, era que por aí que o povo tinha que pensar, mas tinha que conhecer, o que o pessoal conhece é o imediatismo, eu tenho que enfrentar esse negócio, eu tenho que comprar o bom, fulano compra, eu também compro, é essa corrida do tempo, é uma falta de informação e de formação da sociedade para um modelo diferente (Entrevista realizada com Manoel Evangelista, 2006, grifo meu).

A solidariedade é muito necessária, até porque ainda não pegou. $\mathrm{O}$ difícil é as pessoas entenderem que ser solidário e trabalhar o cooperativismo. Tem muita gente que bota na cabeça que trabalhar o cooperativismo é repartir o lucro e náo sabem que tem que repartir tudo. A primeira coisa que tem que repartir é o trabalho, a força de trabalho, se alguém faz e alguém deixa de fazer fica difícil trabalhar. É difícil colocar nessas pessoas o que é solidário, se eu não sou solidário na hora dos meus deveres como é que quero ser na hora de receber. Está na cabeça de muita gente que ser solidário é repartir o lucro, mas náo sabem que a tem que começar a repartir a partir $\mathrm{da}$ limpeza da casa, do conselho, do bate-papo, tudo tem que ser dividido. E, a conversa é a principal, porque se você não troca idéias dificilmente essa coisa vai dar certo, se a pessoa é muito calada o pensamento para dentro, dificilmente da certo com ele. Gente que senta para fazer o trabalho e não quer conversa com ninguém essas pessoas dificilmente vão dar certo desenvolver um trabalho solidário (Entrevista realizada com Manoel Evangelista, 2006, grifo meu).

\section{Solidariedade, Sociedade \&Economia}

Como vimos nas falas acima, nosso poeta confere à solidariedade um papel central no processo de mudança social, náo se trata de um argumento isolado no mundo contemporâneo, pois vários autores contemporâneos e atores políticos atribuem à solidariedade um papel relevante no combate à pobreza. Martins \& Nunes (2004), em resposta aos impactos nefastos do modelo capitalista na era informacional e especulativa propóem um resgate da moral da solidariedade e de pertencimento social. Os autores estão alinhados ao pensamento anti-utilitarista dirigido por Alain Caillé (2002 e 2003) na França ${ }^{17}$. Este autor inspirado em Émile Durkheim e Marcel Mauss, realiza uma crítica às políticas de corte neoliberal e resgata as noções de solidariedade e dádiva para refletir sobre processos contemporâneos, como o associativismo, a democracia e a economia.

O pensamento anti-utilitarista se contrapóe ao neoliberalismo e privilegia em sua análise os aspectos sistêmicos que se expressam nas ações dos grupos sociais no enfretamento à pobreza, sua proposta é política e clama por mudança social. E, neste processo de mudança a solidariedade construída nas relaçóes sociais dos grupos desempenha papel central, como ar- 
gumentam vários autores contemporâneos no Brasil e França, tais como, Godbout (2002), Laville (2004), Martins (2002 e 2004), França Filho (2004 e 2006), Chanial (2004), Sylvian Dzimira (2004), dentre outros.

Seguindo a linha de argumentação proposta pelo Movimento Anti-Utilitarista em Ciências Sociais - M.A.U.S.S., dirigido por Alain Caillé na França, que critica o pensamento economicista e as práticas neoliberais contemporâneas, me pergunto, se em 2011 poderíamos atribuir à solidariedade o potencial de evitar a desagregação do tecido social? Ela poderia se constituir como uma fonte fecunda que levasse à emancipação social? Teria a solidariedade o potencial de combater a pobreza, a desigualdade de renda e a exclusão social? A solidariedade poderia servir de base à formação de um novo modelo econômico, a economia solidária, fundada em novas formas de sociabilidades, em novos valores e em uma nova ética?

Não há respostas simples. Polanyi, refletindo sobre a universalidade do sistema econômico e das relaçóes de mercado, refere-se às experiências das sociedades ditas primitivas, nas quais a atividade econômica está embedded, imersa ou submersa em relaçóes sociais, em contraposição às sociedades industriais capitalistas, nas quais há supostamente uma autonomização da esfera econômica e uma subordinação das demais esferas ao plano econômico: "Em vez de a economia estar embutida nas relações sociais, são as relaçôes sociais que estão embutidas no sistema econômico" (Polanyi, 2000, p. 77).

Assim, nas sociedades ditas primitivas, é a própria troca ancorada na reciprocidade, na redistribuição e imersa em relaçóes sociais que configura um sistema econômico que garante a coesão e a estabilidade do tecido social. Nas sociedades industriais, é o próprio sistema econômico fundado sob uma economia de mercado "auto-regulado" que desagrega o tecido social. Polanyi (Op. cit., p. 51) refere-se à experiência da Inglaterra nos séculos XVIII e XIX e indaga: “Que 'moinho satânico' foi esse que triturou os homens transformando-os em massa?"

Seguindo a mesma linha de raciocínio, Maurice Godelier (2001, p. 310-14) identifica o paradoxo das sociedades capitalistas na própria dinâmica da acumulação capitalista como principal fonte de exclusão social. Para o autor, existe "inegavelmente no coração do capitalismo uma fonte permanente de desigualdades sociais", que repousa no fato de que a "sociedade só vive e prospera, portanto, ao preço de um déficit permanente de solidariedade". "Que lugar resta para o dom em nossas sociedades ocidentais?" indaga o autor. $\mathrm{O}$ dom está em vias de voltar a ser uma condição socialmente necessária à reconstrução do tecido social, conclui Godelier. Assim, podemos pensar que nosso poeta não está solitário em seu pensamento.

\section{Consideraçóes finais}

Após vinte anos de lutas sociais, pequenas mudanças chegaram ao Conjunto Palmeiras. $\mathrm{O}$ bairro hoje dispóe de transporte público, postos de saúde, creches e escolas de ensino médio e fundamental, o lixão já não mais existe. A violência de gênero ganhou visibilidade social e passou a ser debatida na comunidade. A cooperativa das mulheres costureiras continua ativa e o bairro é famoso devido ao Banco Palmas. Um banco comunitário de desenvolvimento que concede crédito à comunidade seguindo os princípios de uma economia solidária, sua experiência é conhecida na França e nos países da América Latina, tornou-se objeto de pesqui$\mathrm{sa}^{18} \mathrm{e}$ foi transplantada para vários países como exemplo paradigmático de uma economia plural (Polany, Op. cit.) ${ }^{19}$. Mas, isto já é assunto para outro artigo.

Considero, entretanto, significativas as (micro) mudanças sociais (citadas acima) que ocorre- 
ram na vida dessas comunidades, especialmente, a conquista da capacidade de mobilização, organização social e de uma consciência política reflexiva que se distancia da lógica patrimonialista ${ }^{20}$.

$\mathrm{Da}$ perspectiva da abordagem biográfica, especialmente das complexas relaçóes entre biografia e contexto sinalizadas no inicio do artigo, podemos considerar que as mudanças sociais na comunidade foram apreendidas neste texto a partir da narrativa biográfica de um poeta popular nascido no sertão do Ceará, que, historicamente nega a sua condição social e ao longo de sua trajetória re- inventa a si mesmo como um militante da economia solidária que crê na utopia da nova sociedade, assim como, vários personagens do Conjunto Palmeiras que com suas açóes cotidianas - pouco a pouco, estão re-significando a estrutura social.

\section{Solidarity economy and world view: a bio-} graphical perspective

abstract This paper presents a biographical narrative of a popular poet born in the backwoods of the State of Ceará. The biographical narrative of Manoel de Brito Evangelista leads us to a foray into the symbolic universe of a backcountry man who transforms himself with and and within history. Following the sign of the times, our poet is contemporary, a man of his time. From a small landless farmer at Cearás backwoods, becomes a critic of neoliberal politics and militant of solidarity economy at the capital city. In his history there is a geographic and symbolic shift that articulates two levels: structure and history. From the biographical approach developed through the paper we can apprehend its heuristic value for the construction of an anthropological understanding of contemporary processes of changes (in poor communities) and of processes involving the (re) signification of the structure by the social subjects.

keywords Biographical narratives. Poor communities. Social change. Structure. Solidarity economy.

\section{Notas}

1. No sentido de fictio - como algo modelado (Geertz, 1989).

2. Cf. Clifford e Marcus (1986), Clifford (2002) e Marcus e Dick (1982).

3. Coraggio (2007) vislumbra a possibilidade de construção de outra economia como contraponto às políticas neoliberais na América Latina. Artigos e comentários sobre Economia social e solidária. Disponível em: <http://revistaotraeconomia.blogspot. com/>. Acesso em: 28/01/2011.

4. Economia solidária é uma categoria polissêmica; portanto, assume distintos significados de acordo com a concepção dos autores e das instituições que a empregam. No Brasil, os termos utilizados são: economia popular, economia solidária, e, em alguns casos, economia social (Lechat, 2002, p.132).

5. Cf. Gonçalves (2009).

6. Sobre a lógica binária e contrastiva, consultar (Durkheim \&Mauss, 1988); Radcliff-Brown (1990) e Lévi-Strauss (1970), dentre outros.

7. A trajetória pode ser concebida "como uma série de posiçóes sucessivamente ocupadas por um mesmo agente (ou um mesmo grupo) num espaço ele próprio um devir submetido a incessantes transformaçôes" [...] "nos estados sucessivos da estrutura da distribuição das diferentes espécies de capital que estão colocados em jogo no campo considerado" (Bourdieu, 2006, p. 189-190).

8. Sahlins (1990), em Ilhas de história, aborda as relaçóes entre a estrutura e história. Para explicar essas relaçóes, o autor toma o mito como seu eixo articulador. Segundo o autor, os eventos são incorporados a partir de uma estrutura simbólica já existente. A cultura é historicamente reproduzida na ação, e a transformação na estrutura ocorre com a história.

9. Cf. Lendas de poesia. Minha história, nossa história, de Manoel Evangelista de Brito, publicado pela Associação Santo Dias. Estive presente na missa de lançamento do livro de poesias na igreja católica do Conjunto Palmeiras, no dia 15 de outubro de 2006. Houve a celebração da missa e depois uma apresentação de danças das meninas do bairro; houve a fala do poeta e de membros da Pastoral e de partidos de esquerda. Trata-se de uma fala social e política, mesclada à espiritualidade oriunda da Pastoral, de combate aos efeitos nefastos do capitalismo na sua fase neoliberal.

10. O Conjunto Palmeiras está situado na região denominada de GrandeJangurussu, próximo ao trecho da Rodovia BR 116 que contorna parte do bairro Mes- 
sejana, na cidade de Fortaleza - CE. Sua população é estimada em 70.000 habitantes.

11. Cf. Gonçalves (2002).

12. A Pastoral Operária é um segmento do setor da Pastoral Social vinculado à Conferência Nacional dos Bispos do Brasil (CNBB). Está presente no Brasil em mais de 80 dioceses e visa criar um espaço de reflexão fundamentado na Bíblia e nos documentos da Igreja para os trabalhadores e trabalhadoras.

13. O projeto foi financiado com recursos do Fundo de Amparo ao Trabalhador (FAT).

14. Processo descrito por Giddens (1991) de circularidade do conhecimento refere-se ao fenômeno de como as teorias e conceitos acadêmicos penetram no mundo social, como uma das conseqüências da modernidade reflexiva.

15. Para uma aplicação contemporânea da noção de enraizamento a partir da abordagem teórica da Sociologia Econômica consultar artigo de Valeria da Vinha (2001).

16. "O que é característico da sociedade capitalista é que a economia é o lócus privilegiado da produção simbólica, neste sentido, o simbolismo econômico é estruturalmente determinante. Em comparação com o mundo 'primitivo' onde o lócus de diferenciação simbólica permanece nas relaçôes sociais, principalmente nas de parentesco, mantendo-se as outras esferas de atividade ordenadas pelas distinçôes operacionais do parentesco" (Sahlins, 1979, p.232).

17. Cf. Movimento Anti-Utilitarista nas Ciências Sociais - M.A.U.S.S. Suas idéias são veiculadas na <www.revuedumauss.com>. No Brasil sob a direção do Professor Paulo Henrique Martins, o pensamento Anti-Utilitarista é divulgado por meio do <www.jornaldomauss.org>.

18. Estudos sobre o Banco Palmas são muitos, dentre eles destaco Paulino (2007); França Filho \& Silva Júnior (2006). Ver também o site do Banco Palmas no sítio: $<$ http://www.bancopalmas.org/site.php>.

19. Uma economia plural é aquela que admite uma pluralidade de princípios do comportamento econômico.

20. Cf. Faoro (2000).

\section{Referências bibliográficas}

BENJAMIN, Walter. "O narrador". In: BENJAMIN, W. Magia e técnica, arte e política: ensaios sobre literatura e história da cultura. Obras escolhidas, vol. 1. São Paulo: Brasiliense, 1985.

BERTAUX, D. L'Approachebiographique. Sa validité mé- thodologique, ses potentialités. Cahiers Internationaux de Sociologie, LXIX, n. 2, Juil.-Déc., p. 198-225, 1980.

BOURDIEU, Pierre. A ilusão biográfica. In: FERREIRA, M; AMADO, J. Usos e abusos da história oral. Rio de Janeiro: FGV, 2006, p.183-192.

BRITO Manoel Evangelista de. Lendas de Poesias. Minha história, Nossa história. Fortaleza: Associação Santo Dias, 2006.

CAILLÉ, Alain. Antropologia do Dom. O terceiro paradigma. Rio de Janeiro: Editora Vozes, 2002.

. Critique de la raison utilitaire. Paris: La Découverte, 2003.

CHANIAL, Philippe. "Todos direitos por todos e para todos: cidadania, solidariedade social e sociedade civil num mundo globalizado". In: MARTINS, Paulo Henrique; NUNES, Brasilmar Ferreira (orgs). A nova ordem social. Perspectivas da solidariedade contemporânea. Brasília: Paralelo, 15. 2004, p. 58-70.

CLIFFORD, James. A experiência etnográfica. Antropologia e literatura no século XX. Rio de Janeiro: UFRJ, 2002.

CLIFFORD, James e MARCUS, George (ed). Writing culture. The poetics and politics of ethnography. Califórnia: University of Califórnia Press, 1986.

CORAGGIO, José Luis. El papel de la Economía Social y Solidaria en la Estrategia de Inclusión Social. Seminario "Pensando en alternativas para el desarrollo", Taller sobre Inclusión Social en América Latina y Ecuador. FLACSO y SENPLADES, Quito, 2007.

CRAPANZANO, Vincent. Tuhami: Portrait of a Moroccan. Chicago: The University of Chicago Press, 1980.

DURKHEIM, Émile; MAUSS, Marcel. "Algumas formas primitivas de classificação”. In: Durkheim, Coleção Grandes Cientistas Sociais. São Paulo: Ática, 1988.

DURKHEIM, Émile. A divisäo do trabalho social, vol. I. $3^{\mathrm{a}}$ ed. Lisboa: Editorial Presença, 1989.

FAORO, Raimundo. Os donos do poder. Formação do patronato político brasileiro. 10a ed. São Paulo: Globo, Publifolha, 2000.

FRANÇA FILHO; SILVA JÚNIOR. "Uma dinâmica associativa emblemática no Nordeste Brasileiro - o caso do Banco Palmas". In: FRANÇA FILHO, LAVILLE (orgs). Ação Pública e economia solidária. Uma perspectiva internacional. Porto Alegre: Editora da UFRGS, 2006, p. 97- 116.

FRANÇA FILHO \& DZIMIRA, Sylvain. "Dádiva e Solidariedade". In: MARTINS, Paulo Henrique; NUNES, Brasilmar Ferreira (orgs). A nova ordem social. Perspectivas da solidariedade contemporânea. Brasília: Paralelo, 15. 2004, p. 136-164. 
GEERTZ, Clifford. A interpretaçâo das culturas. Rio de Janeiro: Livros Técnicos e Científicos, 1989.

GIDDENS, Anthony. As conseqüências da modernidade. São Paulo: Unesp, 1991.

GODELIER, Maurice. O enigma do dom. Rio de Janeiro: Civilização Brasileira, 2001.

GODBOUT, Jacques. "Homo donator versus Homo oeconomicus". In: MARTINS, Paulo Henrique (Org.). $A$ dádiva entre os modernos. Discussão sobre os fundamentos e as regras do social. Rio de Janeiro: Vozes, 2002. p. 63-97.

GONÇALVES, Alicia. Experiências em economia solidária no Estado do Ceará. Campinas: Editora Arte Escrita/ CMU-Publicaçóes/UNICAMP, 2009.

. A modernização do mundo na sua versão econômica: a mundialização do capital. Campinas: Temáticas, v.10, n.19/20, p. 133-170, 2002.

GUSSI, Alcides Fernando. Pedagogias da experiência no mundo do trabalho: narrativas biográficas no contexto de mudanças de um Banco Público Estadual. Tese de Doutorado, Faculdade de Educação, Unicamp, 2004. "Reflexões sobre a abordagem biográfica. Poucas e Boas e Woody Allen". In: Cadernos de Antropologia e Imagem, v. 14, dez, p. 23-38, 2002.

JOSSO, Marie-Christine. "Prefácio". In: SOUZA, Elizeu Clementino de; ABRAHĀO, Maria Helena Menna Barreto (Orgs.). Tempos, narrativas e ficçôes: a invenção de si. Porto Alegre: EDIPUCRS/ EDUNEB, 2006. p. 7-13.

KOFES, Sueli. Uma trajetória em narrativas. Campinas: Autores Associados, 2001.

Experiências sociais, interpretaçôes individuais: histórias de vida, suas possibilidades e limites. Cadernos Pagu. Campinas, n. 3, p.117-142, 1984.

LAVILLE, Jean-Louis. "Com Mauss e Polanyi. Rumo a uma teoria da economia plural”. In: MARTINS, Paulo Henrique; NUNES, Brasilmar Ferreira (orgs). A nova ordem social. Perspectivas da solidariedade contemporânea. Brasília: Paralelo, 15. 2004. p. 42-57.
LECHAT, Noelle Marie Paule. Economia social, economia solidária, terceiro setor: do que se trata? Civitas, Porto Alegre, v. 2, n.1, p. 123-140, 2002.

LEVI, Giovanni. “Usos da biografia”. In: FERREIRA, M; AMADO, J. Usos e abusos da história oral. Rio de Janeiro: FGV, 2006, p.167-182.

LÉVI-STRAUSS, Claude. O pensamento selvagem. São Paulo: Cia Editora Nacional, 1970.

MARCUS, George; DICK, Cushman. Ethnographies as texts. Annual Review of Anthropology, Califórnia, v. 11, p.25-69, 1982.

MARTINS, Paulo Henrique; NUNES, Brasilmar Ferreira (orgs). A nova ordem social. Perspectivas da solidariedade contemporânea. Brasília: Paralelo, 15. 2004.

PASTORAL OPERÁRIA. Experiência de trabalho alternativo. São Paulo: Colegiado Nacional da Pastoral Operária, 2005.

PAULINO, George Lopes. A sócio-economia solidária na experiência do Banco Palmas. In: XIII Congresso Brasileiro de Sociologia, 2007, Recife, 16p.

POLANYI, Karl. A grande transformação: as origens da nossa época. 2 ed. Rio de Janeiro: Elsevier, 2000.

RADCLIFFE- Brown. "O método comparativo em Antropologia social”. In: ZALUAR, Alba. Desvendando máscaras sociais. $3^{\circ}$ ed. Francisco Alves, 1990, p.195210.

SAHLINS, Marshall. Ilhas de histórias. Rio de Janeiro: Jorge Zahar, 1990.

Cultura e razão prática. Rio de Janeiro: Jorge Zahar, 1979.

SOUZA, Elizeu Clementino de; ABRAHÃO, Maria Helena Menna Barreto (Orgs.). Tempos, narrativas e ficçôes: a invenção de si. Porto Alegre: EDIPUCRS:EDUNEB, 2006.

VINHA, Valeria da. Polanyi e a Nova Sociologia Econômica: uma Aplicaçâo Contemporânea do Conceito do Enraizamento Social, Revista Econômica, v. 3, n. 2, p. 207-230, 2001.

\section{autora Alicia Ferreira Gonçalves}

Doutora em Ciências Sociais / Unicamp

Professora adjunta de Ciências Sociais da UFPB

Recebido em 15/02/2011

Aceito para publicação em 26/09/2011 